\title{
Detection Tool for Unbalanced Bids
}

\author{
Babak Nikpour ${ }^{1}$, Ahmed Senouci², Neil Eldin² \\ ${ }^{1}$ Field Project Controls, Arcadis, Chicago, USA \\ ${ }^{2}$ Department of Construction Management, University of Houston, Houston, USA \\ Email: babak.nikpour@arcadis.com, asenouci@central.uh.edu,neldin@uh.edu
}

How to cite this paper: Nikpour, B., Senouci, A. and Eldin, N. (2017) Detection Tool for Unbalanced Bids. Open Journal of Civil Engineering, 7, 409-422. https://doi.org/10.4236/ojce.2017.73028

Received: July 21, 2017

Accepted: August 20, 2017

Published: August 23, 2017

Copyright (c) 2017 by authors and Scientific Research Publishing Inc. This work is licensed under the Creative Commons Attribution International License (CC BY 4.0).

http://creativecommons.org/licenses/by/4.0/

\begin{abstract}
Unbalanced bidding is a cash flow management strategy that is recognized as an illegal/disqualifying practice by public owners; and unethical practice by most private owners. This practice provides the awarded bidder with unjustified advantages at the expense of the owner. Unfortunately, limited tools and techniques are currently available to identify and detect unbalanced bids during the evaluation process. This paper presents an innovative detection tool to identify unbalanced bids in unit price contracts during the bid evaluation process. The proposed technique develops BMDI graphs to visualize total markup variation patterns during the project lifetime to detect unbalanced bids. The proposed method also uses Monte Carlo simulation to take in consideration the impact of cost uncertainties and risks. An illustrative example was presented to show the capabilities and features of the proposed method in determining the status of submitted bids during the evaluation process.
\end{abstract}

\section{Keywords}

Unbalanced Bidding, Detection, Bid Evaluation, Construction Projects, Monte-Carlo Simulation

\section{Introduction}

Cash flow management is a concern for contractors as payments from owners lag behind project expenditures. This time lag adversely affects the contractors' cash flow and cause contractors to partially finance their projects. Unbalanced bidding, which is considered an illegal/unethical practice, may be used as a risky mitigation strategy [1]. Unbalanced bids can occur in fixed and unit price contracts. However, this study focuses on unbalanced bids in unit price contracts. In unit price contracts, unbalanced bids can be prepared by manipulating the item's prices without affecting the total bid price [2]. Unfortunately, it is usually diffi- 
cult for owners to determine the existence and/or extent of potential inflation/deflation of bid item prices [2]. The difficulty comes from the fact that the award decision depends on the total bid price. The variations in the items' unit prices are usually not considered. They may be due to legitimate reasons such as variations in the bidders' expertise. They may also be due to a deliberate manipulation of unit prices to hide certain advantages, construction means, or proprietary technologies, or due to an honest mistake or a bad business decision.

Cattell [2] classifies unbalanced bids into three groups, namely, Front-End loaded, Back-End loaded, and Quantity Error Exploitation. Front-End loaded bids inflate the prices of early stage activities to positively impact the contractor cash-in flow. They usually result in owner overpayments when the value of time is considered [3]. In other words, Front-End bids allow for an interest-free loan from the owner to the contractor. Equally important, the overpayments would weaken the owner's position and reduce the contractor's incentives to complete the project. Back-End loading consists of inflating the prices of late schedule items. This pricing strategy is not common in relatively short duration construction projects that located in low inflation rate countries such as the United States. In Quantity Error Exploitation scenarios, the contractor increases the unit price of items in which actual quantities are expected to exceed the ones stated in the bid documents [2]. For example, in one of the contracts awarded by the Florida Department of Transportation (FDOT), the bid winner, inadvertently or deliberately, offered a high unit price (i.e., $\$ 420 / \mathrm{ft}$ versus $\$ 171 / \mathrm{ft}$ ) for trench support sheet. As the owner's offered quantity was $30 \%$ of the actual one (i.e., $500 \mathrm{ft}$ versus $1729 \mathrm{ft}$ ) the contractor was able to submit the lowest bid. Unfortunately, FDOT did not detect this problem, which resulted in additional unnecessary cost of $\$ 516,180$ [4]. Quantity Error Exploitation bids, which are more difficult to detect than other types, may have severe consequences on the owner cost.

The US public and private sectors have different approaches to unbalanced bids. The federal code of regulation (48 C.F.R. $\$ 15.404-1$ (g)) forbids unbalanced pricing because of its adverse consequences on performance risk and payments. However, unbalanced bids are not forbidden in the US private construction industry sector. However, they are considered as unethical and risky acts. Moreover, the private sector strives to detect unbalanced bids in advance as a preventive action.

Significant research work has been conducted to address unbalanced bids. However, most of the published research work has focused on developing optimization models to help contractors maximize their profit while submitting the lowest possible bid price [5] [6] [7]. Moreover, limited tools and techniques have been published to help owners/clients detect and prevent unbalanced bids during the tender evaluation process. This paper presents an innovative detection tool for unit price projects that helps owners/clients to visualize the distribution of markup along the project timeline and detect unbalanced bids. 


\section{Literature Review}

A literature review was conducted to determine the state-of-the-art in the area of unbalanced bids. In 2004, the American Association of State Highway and Transportation Officials (AASHTO) conducted a survey about how State Department of Transportation (DOT) agencies were handling unbalanced bids [8]. A total of 27 State DOTs responded to the survey. The survey results showed that most states did not have any formal procedure to detect unbalanced bids. Florida DOT used a statistical analysis approach to define an acceptable range for each line item price. It also developed a computer program that automatically detects any out of range item price. Texas DOT defined an acceptable range for each line item based on engineering estimates. Then, the possible monthly payments trends of the first and second bidders were computed using the proposed bidders' time schedules. The two trends were then compared to help the evaluators find out unbalanced bids. North Carolina DOT used a contractual provision to prevent unreasonable line item prices. Unit or lump sum prices were considered reasonable and acceptable if they were close to the average of the engineering estimate and other bidder prices. Wang [9] developed a bidder-based quantitative approach that examined separately every line item price using four tasks, namely, preparation, evaluation, explanation, and adjustment. Arditi and Chotibhongs [10] developed two automated Excel spreadsheet processing models to detect mathematically and materially unbalanced bids. The models compare the price of each line item against engineering estimates and other bidders' prices. Shrestha and Joshi [11] conducted a statistical analysis on a historical data set that was collected from 264 bids for 70 road projects to investigate if the submitted bids were unbalanced. Skitmore and Cattell [12] used simulation to investigate the impact of two common errors commonly made by bid evaluators. Hyari [13] developed a bid rebalancing model that is based on prevention of unbalanced bids rather than their detection. The model adjusts all line item prices of the lowest bids.

\section{Simulation Methods}

Only a limited number of researchers have considered uncertainty and risk in their models. Hoogenboom [5] presented a simulation optimization technique that considered the possibility of changes in estimated quantities. Liu et al. [7] developed an optimization model for front-loaded bids. They considered uncertainty by estimating the fluctuation ranges of engineering quantities. Afshar and Amiri [14] [15] developed a fuzzy linear programing model to optimize a bidding strategy. They considered work quantities as fuzzy numbers. Hyari et al. [4] developed a Monte Carlo simulation-based detection model. The model quantifies risk by considering uncertainty in the work quantities. The model provides the owner/client with a new decision-making tool to select the bid that has a better probability in providing the best bid value. It can also perform a sensitivity analysis to determine the risk impact of the identified unknowns. 


\section{Method Formulation}

\subsection{Bid Markup Distribution Index Graphs}

The total bid price is computed by adding expected profits to estimated construction and overhead costs. Project construction cost can be determined fairly accurately using project documents, such as drawings and specifications. However, overhead costs and profit are more difficult to estimate accurately and can be affected by many factors, such as market conditions, or bidders' need for the job [16]. The amount of general overhead cost and profit is often specified as a markup amount or a percentage of total bid price, for example, $15 \%$ of total construction cost [16]. The markup amount is then distributed among project construction activities. The distribution of the overall markup amount in each activity can affect cash-flow of the bidder [17]. For example, by inflating the markup amount for early activities and deflating it for late activities, bidders can improve their cash-flow and reduce their interest costs [16]. Furthermore, the bidder's profit can be increased by manipulating the markup distribution in case of expected errors in the quantity of work provided by the owner's representative.

The markup distribution in fixed and unit price contracts' biddings is different from each other. However, the basic idea of distributing the overall markup to activities is similar. One of the methods to distribute the overall markup is to allocate the markup amounts proportionally to the cost of each activity. Mincks and Johnston [17] used the activity cost to total cost ratios to compute the activity markup amounts. This is a simple method that leads to a "balanced" activity markup. However, a "balanced" markup distribution does not likely leads to an improved cash flow. That's why, bidders frequently use "unbalanced" markup distributions methods to improve their project cash flows.

Unbalanced bidding is defined as an uneven distribution of project items' markup without affecting the total desired markup [12]. In frond-end loaded unbalanced bids, the markup of early and late activities will be inflated and deflated, respectively. As a result, the project experiences a bigger markup during its early construction activities than late ones. Figure 1 presents a typical Bid Markup Distribution Index Graph (BMDI) for front-end loaded bids. It shows a markup decreasing trend over the project duration. On the other hand, the markup of early and late activities in back-end loaded bids are deflated and inflated, respectively. Figure 2 presents a typical BMDI graph for back-end loaded bids, which shows a markup increasing trend over the project duration. In quantity error exploitation bids, few item markups will be inflated and some others will be deflated to keep the total bid price unchanged [2] [18]. This causes uneven markup fluctuations over the project timeline. Figure 3 presents a typical BMDI graph for quantity error exploitation unbalanced bids, which shows markup spikes over the project duration. Finally, a balanced bid will always show an even markup distribution among all activities and also periodically even total markup along the project timeline [18]. Figure 4 presents a typical BMDI graph 


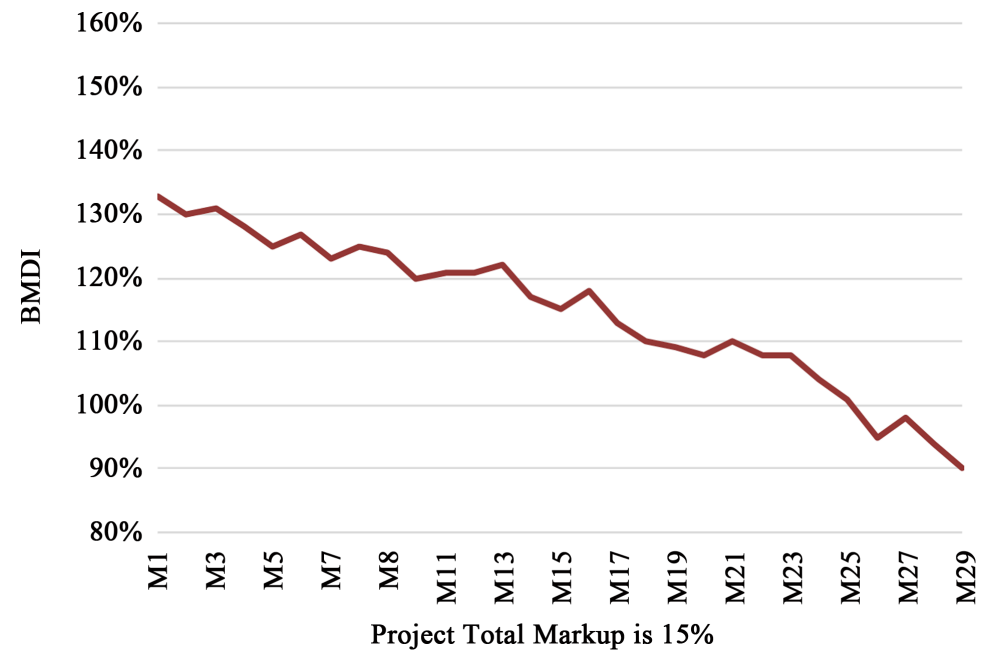

Figure 1. BMDI graph for front-end loaded bids.

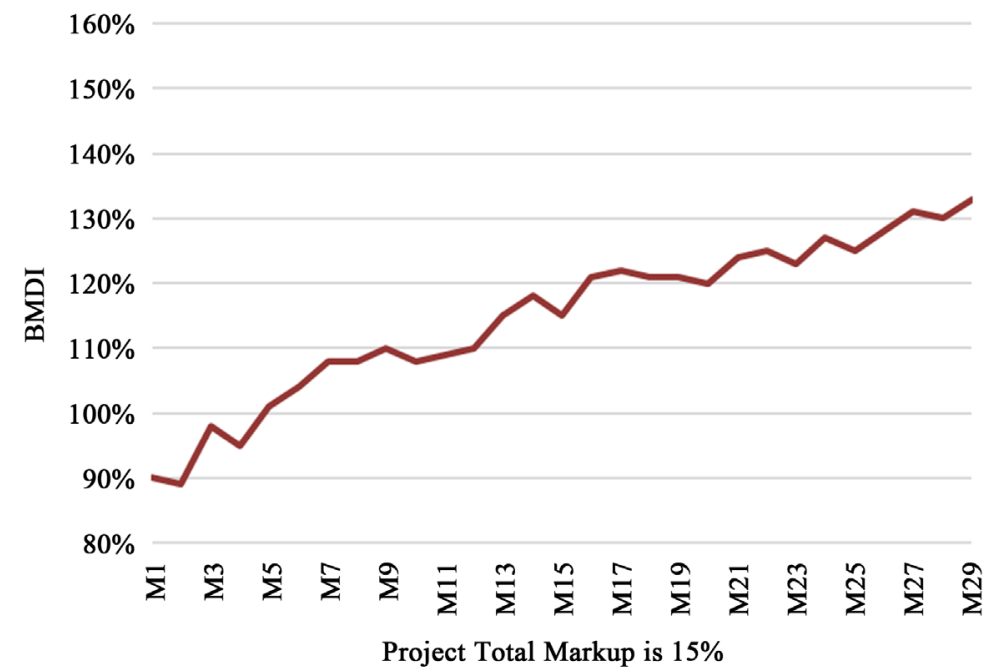

Figure 2. BMDI graph for back-end loaded bids.

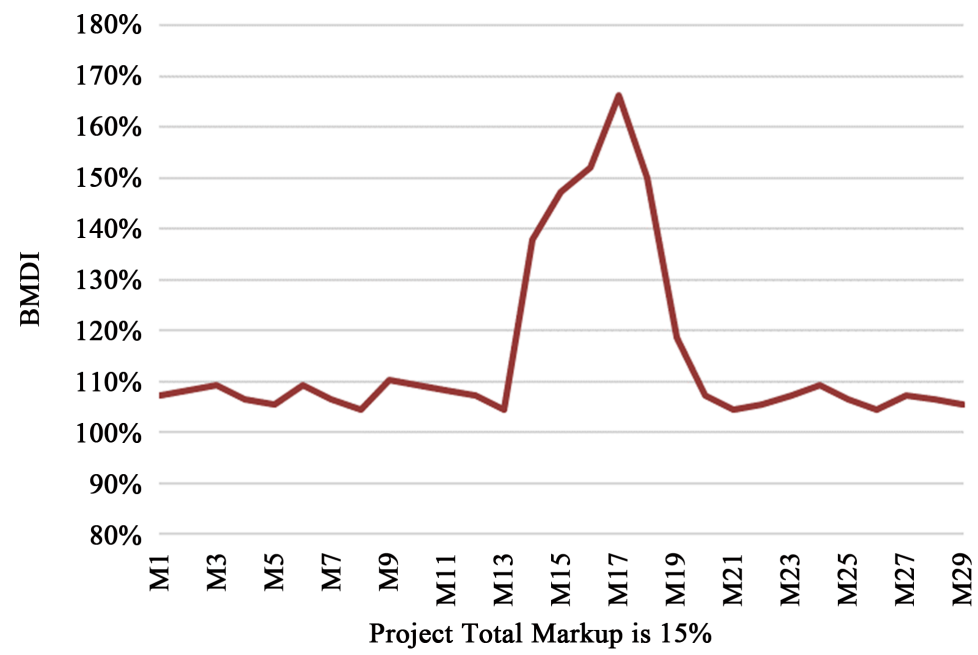

Figure 3. BMDI graph for quantity error exploitation loaded bids. 


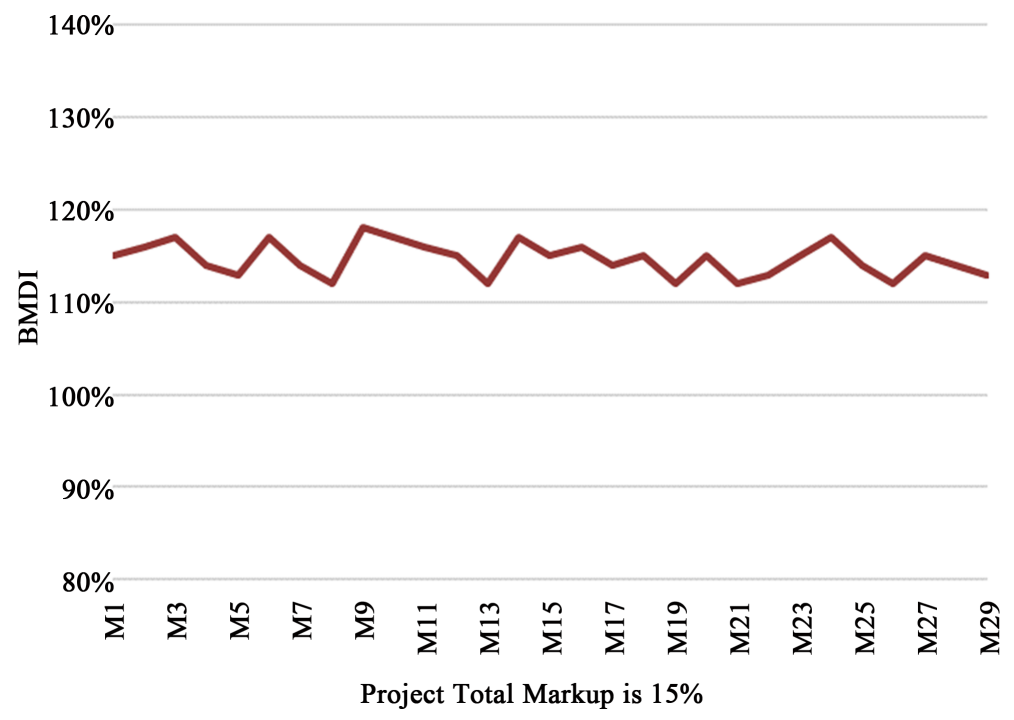

Figure 4. BMDI graph for balanced bids.

for balanced bids, which shows a relatively constant markup distribution along the project life time.

\subsection{Proposed Method Development}

The proposed method develops bid BMDI graphs to visualize total markup variation patterns during the project lifetime and to detect unbalanced bids. It also uses Monte Carlo simulation to take in consideration the impact of cost uncertainties and risks. Monte Carlo simulation uses random generated numbers to evaluate the impact of uncertain factors on the final results. Triangular probability distributions were used herein to simulate possible bid item unit costs and quantities. The upper, lower, and most likely values can be estimated using internal company records, commercially published books, or expert judgements. The proposed method consists of the following three major computational steps:

\subsubsection{Input Data}

For each bid item, all unit prices are read and compiled. A pseudo code of the computational tasks in this step is shown below.

For each bid item $i(i=1, \cdots, I)$, where $I=$ number of bid items.

For each bidder $m(m=1, \cdots, M)$, where $M=$ number of bidders.

- Read bid item unit price- $B I U P(i, m)$.

- Read bid item quantity-BIEQ $(i)$.

\subsubsection{Monte-Carlo Simulation}

Triangular probability distributions were used herein for BIEQs and BIEUCs. Moreover, the number of simulation iterations was set equal to 5000. The Monte-Carlo simulation is described using the following pseudo code:

For each bid item $i(i=1, \cdots, I)$, where $I=$ number of bid items.

- Estimate bid item unit cost-BIEUC (i) using the following equation: 


$$
\operatorname{BIEUC}(i)=\frac{\left(\frac{\sum_{m=1}^{M} B I U P(i, m)}{M}\right)}{1+\frac{\% \text { Markup }}{100}}
$$

where \% Markup = percent cost markup (typically equal to 15\%) and $M=$ number of bids.

- Calculate bid item price $B I E C(i)$ using the following equation:

$$
\operatorname{BIEC}(i)=B I E Q(i) * B I E U C(i)
$$

- Estimate the minimum, maximum, and most likely values of bid item quantity, $B I E Q(i)$

- Estimate the minimum, maximum, and most likely values of bid item unit cost, $\operatorname{BIEUC}(i)$.

For each simulation iteration $r(r=1, \cdots, R)$, where $R=$ total number of iterations.

For each bid item $i(i=1, \cdots, I)$, where $I=$ number of bid items.

- Generate random values for $\operatorname{BIEQ}(r, \hat{i})$ and $\operatorname{BIEUC}(r, \hat{i})$.

- For each bidder and for each monitoring period $(t=1, \cdots, T)$, where $T=$ total number of monitoring periods.

o Compute $\operatorname{BMDI}(r, m, t)$ using the following equation:

$$
\operatorname{BMDI}(r, m, t)=\frac{\sum_{i=1}^{I} \frac{\operatorname{BIEP}(r, i, m)}{\operatorname{Dur}(i, m)} * \operatorname{Act}(i, m, t)}{\sum_{i=1}^{I} \frac{\operatorname{BIEC}(r, i)}{\operatorname{Dur}(i, m)} * \operatorname{Act}(i, m, t)}
$$

where: $B M D I(r, m, t)=$ bid markup distribution index in iteration $r$ for bidder $\mathrm{m}$ during monitoring period $t, \operatorname{Dur}(i, m)=$ scheduled duration of bid item $i$, offered by bidder $m$; $A c t(i, m, t)=$ number of active periods of bid item $i$, counted in the offered time schedule by bidder $\mathrm{m}$, for monitoring period $t$.

\subsubsection{BMDI Graphs}

All generated BMDI values will be used herein to generate five separate tend lines, namely, minimum, 1st quarter, median, 3rd quarter, and maximum. The bid balance status (i.e., balanced or unbalanced) and potential risks will be determined by interpreting the patterns of these trend lines.

The computational tasks for the generation of the BMDI trend lines are summarized using the following pseudo code:

For each bidder $m(m=1, \cdots, M)$, where $M=$ total number of bidders.

For each monitoring period $t(t=1, \cdots, T)$, where $T=$ total number of monitoring periods.

- Determine the minimum, 1st quarter, median, 3rd quarter, and maximum BMDI values.

- Draw the trend lines by connecting the BMDI points along the project time line. 
- Analyze the bidders BMDI graphs to determine the status of the submitted bids.

\section{Illustrative Example}

An illustrative example is used herein to show the capabilities and features of the proposed method. It consists of a 13-activity construction project and is 30 weeks long. BMDI values will be calculated and monitored for 8 months. Figure 5 shows the Gantt chart project schedule.

\subsection{Balanced Bids}

In a balanced bid, the project total markup is distributed evenly among project activities. Table 1 summarizes the computation of the BMDI values in the case of a balanced bid.

\begin{tabular}{|c|c|c|c|c|c|c|c|c|c|}
\hline \multirow{2}{*}{ Tasks } & \multirow{2}{*}{\begin{tabular}{|l}
$\begin{array}{l}\text { Duration } \\
\text { (Weeks) }\end{array}$ \\
\end{tabular}} & \multirow{2}{*}{\begin{tabular}{llll}
\multicolumn{3}{c}{ Month 1 } \\
w1 & w2 & w3 & w4 \\
\end{tabular}} & \multirow{2}{*}{ 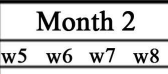 } & \multirow{2}{*}{\begin{tabular}{|c|} 
Month 3 \\
w9 w10 w11 w
\end{tabular}} & \multirow{2}{*}{\begin{tabular}{|c|} 
Month 4 \\
w13 w14 w15 w16 wl? \\
\end{tabular}} & \multirow{2}{*}{\begin{tabular}{|c|} 
Month 5 \\
w18 w19 w20 w21 \\
\end{tabular}} & \multirow{2}{*}{\begin{tabular}{|c} 
Month 6 \\
w22 w23 w24 w25 \\
\end{tabular}} & \multirow{2}{*}{\begin{tabular}{|c|} 
Month 7 \\
w26 w27 w28 w2
\end{tabular}} & \multirow{2}{*}{$\begin{array}{r}\text { Month } 8 \\
\text { w30 w31 w32 }\end{array}$} \\
\hline & & & & & & & & & \\
\hline A & 4 wks & & & & & & & & \\
\hline B & 6 wks & & & & & & & & \\
\hline C & 8 wks & & & & & & & & \\
\hline D & $4 \mathrm{wks}$ & & & & & & & & \\
\hline $\mathrm{E}$ & 8 wks & & & & & 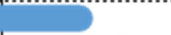 & & & \\
\hline $\mathrm{F}$ & 8 wks & & & & & & & & \\
\hline G & 4 wks & & & & & & & & \\
\hline $\mathrm{H}$ & $5 \mathrm{wks}$ & & & & & & & & \\
\hline I & 4 wks & & & & & & ? & & \\
\hline $\mathrm{J}$ & 6 wks & & & & & & & & \\
\hline $\begin{array}{l}\mathrm{K} \\
\mathrm{L}\end{array}$ & $\begin{array}{l}4 \text { wks } \\
4 \text { wks }\end{array}$ & & & & & & & & \\
\hline $\mathrm{M}$ & 2 wks & & & & & & & & 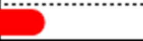 \\
\hline
\end{tabular}

Figure 5. Gantt chart project schedule.

Table 1. Balanced loaded bid scenario.

\begin{tabular}{|c|c|c|c|c|c|c|c|c|c|}
\hline \multirow{2}{*}{ Bid items } & \multirow{2}{*}{ BIUP } & \multirow{2}{*}{ BIEUC } & \multirow{2}{*}{ Markup } & \multicolumn{3}{|c|}{ BIEQ } & \multicolumn{3}{|c|}{ BIEUC } \\
\hline & & & & Min & Most likely & Max & Min & Most likely & Max \\
\hline A & $4.57 \$ / \mathrm{m}$ & $4.00 \$ / \mathrm{m}$ & $114 \%$ & $68,835 \mathrm{~m}$ & $72,765 \mathrm{~m}$ & $83,160 \mathrm{~m}$ & $3.60 \$ / \mathrm{m}$ & $4.20 \$ / \mathrm{m}$ & $4.60 \$ / \mathrm{m}$ \\
\hline B & $12.78 \$ / \mathrm{m}$ & $11.20 \$ / \mathrm{m}$ & $114 \%$ & $27,930 \mathrm{~m}$ & $30,870 \mathrm{~m}$ & $35,280 \mathrm{~m}$ & $10.08 \$ / \mathrm{m}$ & $11.76 \$ / \mathrm{m}$ & $12.88 \$ / \mathrm{m}$ \\
\hline $\mathrm{C}$ & $5.83 \$ / \mathrm{m}$ & $5.00 \$ / \mathrm{m}$ & $117 \%$ & $33,250 \mathrm{~m}$ & $36,750 \mathrm{~m}$ & $42,000 \mathrm{~m}$ & $4.50 \$ / \mathrm{m}$ & $5.25 \$ / \mathrm{m}$ & $5.75 \$ / \mathrm{m}$ \\
\hline $\mathrm{D}$ & $5.20 \$ / \mathrm{m}$ & $4.55 \$ / \mathrm{m}$ & $114 \%$ & $27,930 \mathrm{~m}$ & $30,870 \mathrm{~m}$ & $35,280 \mathrm{~m}$ & $4.10 \$ / \mathrm{m}$ & $4.78 \$ / \mathrm{m}$ & $5.23 \$ / \mathrm{m}$ \\
\hline $\mathrm{E}$ & $11.53 \$ / \mathrm{m}$ & $10.00 \$ / \mathrm{m}$ & $115 \%$ & $25,935 \mathrm{~m}$ & $28,665 \mathrm{~m}$ & $32,760 \mathrm{~m}$ & $9.00 \$ / \mathrm{m}$ & $10.50 \$ / \mathrm{m}$ & $11.50 \$ / \mathrm{m}$ \\
\hline $\mathrm{F}$ & $5.48 \$ / \mathrm{m}$ & $4.80 \$ / \mathrm{m}$ & $114 \%$ & $53,200 \mathrm{~m}$ & $58,800 \mathrm{~m}$ & $67,200 \mathrm{~m}$ & $4.32 \$ / \mathrm{m}$ & $5.04 \$ / \mathrm{m}$ & $5.52 \$ / \mathrm{m}$ \\
\hline G & $7.40 \$ / \mathrm{m}$ & $6.20 \$ / \mathrm{m}$ & $119 \%$ & $53,865 \mathrm{~m}$ & $59,535 \mathrm{~m}$ & $68,040 \mathrm{~m}$ & $5.58 \$ / \mathrm{m}$ & $6.51 \$ / \mathrm{m}$ & $7.13 \$ / \mathrm{m}$ \\
\hline $\mathrm{H}$ & $6.03 \$ / \mathrm{m}$ & $5.30 \$ / \mathrm{m}$ & $114 \%$ & $33,250 \mathrm{~m}$ & $36,750 \mathrm{~m}$ & $42,000 \mathrm{~m}$ & $4.77 \$ / \mathrm{m}$ & $5.57 \$ / \mathrm{m}$ & $6.10 \$ / \mathrm{m}$ \\
\hline I & $11.90 \$ / \mathrm{m}$ & $10.50 \$ / \mathrm{m}$ & $113 \%$ & $21,280 \mathrm{~m}$ & $23,520 \mathrm{~m}$ & $26,880 \mathrm{~m}$ & $9.45 \$ / \mathrm{m}$ & $11.03 \$ / \mathrm{m}$ & $12.08 \$ / \mathrm{m}$ \\
\hline$J$ & $9.72 \$ / \mathrm{m}$ & $8.50 \$ / \mathrm{m}$ & $114 \%$ & $29,260 \mathrm{~m}$ & $32,340 \mathrm{~m}$ & $36,960 \mathrm{~m}$ & $7.65 \$ / \mathrm{m}$ & $8.93 \$ / \mathrm{m}$ & $9.78 \$ / \mathrm{m}$ \\
\hline K & $4.04 \$ / \mathrm{m}$ & $3.50 \$ / \mathrm{m}$ & $115 \%$ & $51,870 \mathrm{~m}$ & $57,330 \mathrm{~m}$ & $65,520 \mathrm{~m}$ & $3.15 \$ / \mathrm{m}$ & $3.68 \$ / \mathrm{m}$ & $4.03 \$ / \mathrm{m}$ \\
\hline $\mathrm{L}$ & $7.21 \$ / \mathrm{m}$ & $6.30 \$ / \mathrm{m}$ & $114 \%$ & $53,200 \mathrm{~m}$ & $58,800 \mathrm{~m}$ & $67,200 \mathrm{~m}$ & $5.67 \$ / \mathrm{m}$ & $6.62 \$ / \mathrm{m}$ & $7.25 \$ / \mathrm{m}$ \\
\hline M & $57.40 \$ / \mathrm{m}$ & $50.20 \$ / \mathrm{m}$ & $114 \%$ & $5320 \mathrm{~m}$ & $5880 \mathrm{~m}$ & $6720 \mathrm{~m}$ & $45.18 \$ / \mathrm{m}$ & $52.71 \$ / \mathrm{m}$ & $57.73 \$ / \mathrm{m}$ \\
\hline \multicolumn{2}{|c|}{ Total Bid Value } & $3,813,698 \$$ & & & & & & & \\
\hline
\end{tabular}


Figure 6 shows that the 5 BMDI trend lines are almost horizontally during the project time. Moreover, the minimum maximum and middle trend lines follow the same direction.

\subsection{Front-End Loaded Bids}

In front-end loaded bids, early stage activities have bigger markups than late stage activities. Table 2 summarizes the computation of BMDI values in a frontend loaded bid scenario. Figure 7 shows a decreasing pattern for the 5 BMDI trend lines. Moreover, the minimum maximum and middle trend lines follow the same direction.

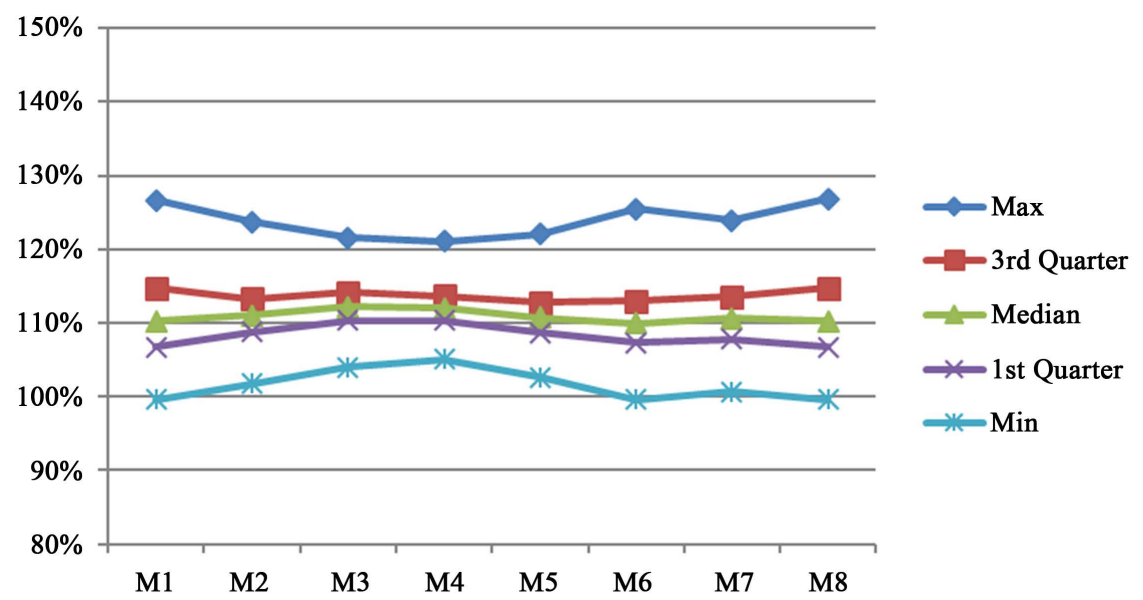

Figure 6. BMDI values variation with project time in a balanced bid.

Table 2. Front-End loaded bid scenario.

\begin{tabular}{|c|c|c|c|c|c|c|c|c|c|}
\hline \multirow{2}{*}{ Bid items } & \multirow{2}{*}{ BIUP } & \multirow{2}{*}{ BIEUC } & \multirow{2}{*}{ Markup } & \multicolumn{3}{|c|}{ BIEQ } & \multicolumn{3}{|c|}{ BIEUC } \\
\hline & & & & Min & Most likely & $\operatorname{Max}$ & Min & Most likely & $\operatorname{Max}$ \\
\hline A & $5.22 \$ / \mathrm{m}$ & $4.00 \$ / \mathrm{m}$ & $130 \%$ & $65,835 \mathrm{~m}$ & $72,765 \mathrm{~m}$ & $83,160 \mathrm{~m}$ & $3.60 \$ / \mathrm{m}$ & $4.20 \$ / \mathrm{m}$ & $4.60 \$ / \mathrm{m}$ \\
\hline B & $13.37 \$ / \mathrm{m}$ & $11.20 \$ / \mathrm{m}$ & $119 \%$ & $27,930 \mathrm{~m}$ & $30,870 \mathrm{~m}$ & $35,280 \mathrm{~m}$ & $10.08 \$ / \mathrm{m}$ & $11.76 \$ / \mathrm{m}$ & $12.88 \$ / \mathrm{m}$ \\
\hline $\mathrm{C}$ & $6.08 \$ / \mathrm{m}$ & $5.00 \$ / \mathrm{m}$ & $122 \%$ & $33,250 \mathrm{~m}$ & $36,750 \mathrm{~m}$ & $42,000 \mathrm{~m}$ & $4.50 \$ / \mathrm{m}$ & $5.25 \$ / \mathrm{m}$ & $5.75 \$ / \mathrm{m}$ \\
\hline $\mathrm{D}$ & $5.76 \$ / \mathrm{m}$ & $4.55 \$ / \mathrm{m}$ & $127 \%$ & $27,930 \mathrm{~m}$ & $30,870 \mathrm{~m}$ & $35,280 \mathrm{~m}$ & $4.10 \$ / \mathrm{m}$ & $4.78 \$ / \mathrm{m}$ & $5.23 \$ / \mathrm{m}$ \\
\hline $\mathrm{E}$ & $11.65 \$ / \mathrm{m}$ & $10.00 \$ / \mathrm{m}$ & $117 \%$ & $25,935 \mathrm{~m}$ & $28,665 \mathrm{~m}$ & $32,760 \mathrm{~m}$ & $9.00 \$ / \mathrm{m}$ & $10.50 \$ / \mathrm{m}$ & $11.50 \$ / \mathrm{m}$ \\
\hline $\mathrm{F}$ & $5.46 \$ / \mathrm{m}$ & $4.80 \$ / \mathrm{m}$ & $114 \%$ & $53,200 \mathrm{~m}$ & $58,800 \mathrm{~m}$ & $67,200 \mathrm{~m}$ & $4.32 \$ / \mathrm{m}$ & $5.04 \$ / \mathrm{m}$ & $5.52 \$ / \mathrm{m}$ \\
\hline G & $7.35 \$ / \mathrm{m}$ & $6.20 \$ / \mathrm{m}$ & $119 \%$ & $53,865 \mathrm{~m}$ & $59,535 \mathrm{~m}$ & $68,040 \mathrm{~m}$ & $5.58 \$ / \mathrm{m}$ & $6.51 \$ / \mathrm{m}$ & $7.13 \$ / \mathrm{m}$ \\
\hline $\mathrm{H}$ & $6.22 \$ / \mathrm{m}$ & $5.30 \$ / \mathrm{m}$ & $117 \%$ & $33,250 \mathrm{~m}$ & $36,750 \mathrm{~m}$ & $42,000 \mathrm{~m}$ & $4.77 \$ / \mathrm{m}$ & $5.57 \$ / \mathrm{m}$ & $6.10 \$ / \mathrm{m}$ \\
\hline I & $11.77 \$ / \mathrm{m}$ & $10.50 \$ / \mathrm{m}$ & $112 \%$ & $21,280 \mathrm{~m}$ & $23,520 \mathrm{~m}$ & $26,880 \mathrm{~m}$ & $9.45 \$ / \mathrm{m}$ & $11.03 \$ / \mathrm{m}$ & $12.08 \$ / \mathrm{m}$ \\
\hline $\mathrm{J}$ & $9.33 \$ / \mathrm{m}$ & $8.50 \$ / \mathrm{m}$ & $110 \%$ & $29,260 \mathrm{~m}$ & $32,340 \mathrm{~m}$ & $36,960 \mathrm{~m}$ & $7.65 \$ / \mathrm{m}$ & $8.93 \$ / \mathrm{m}$ & $9.78 \$ / \mathrm{m}$ \\
\hline K & $3.92 \$ / \mathrm{m}$ & $3.50 \$ / \mathrm{m}$ & $112 \%$ & $51,870 \mathrm{~m}$ & $57,330 \mathrm{~m}$ & $65,520 \mathrm{~m}$ & $3.15 \$ / \mathrm{m}$ & $3.68 \$ / \mathrm{m}$ & $4.03 \$ / \mathrm{m}$ \\
\hline $\mathrm{L}$ & $6.65 \$ / \mathrm{m}$ & $6.30 \$ / \mathrm{m}$ & $106 \%$ & $53,200 \mathrm{~m}$ & $58,800 \mathrm{~m}$ & $67,200 \mathrm{~m}$ & $5.67 \$ / \mathrm{m}$ & $6.62 \$ / \mathrm{m}$ & $7.25 \$ / \mathrm{m}$ \\
\hline M & $50.12 \$ / \mathrm{m}$ & $50.20 \$ / \mathrm{m}$ & $100 \%$ & $5320 \mathrm{~m}$ & $5880 \mathrm{~m}$ & $6720 \mathrm{~m}$ & $45.18 \$ / \mathrm{m}$ & $52.71 \$ / \mathrm{m}$ & $57.73 \$ / \mathrm{m}$ \\
\hline \multicolumn{2}{|c|}{ Total Bid Value } & $3,813,695 \$$ & & & & & & & \\
\hline
\end{tabular}




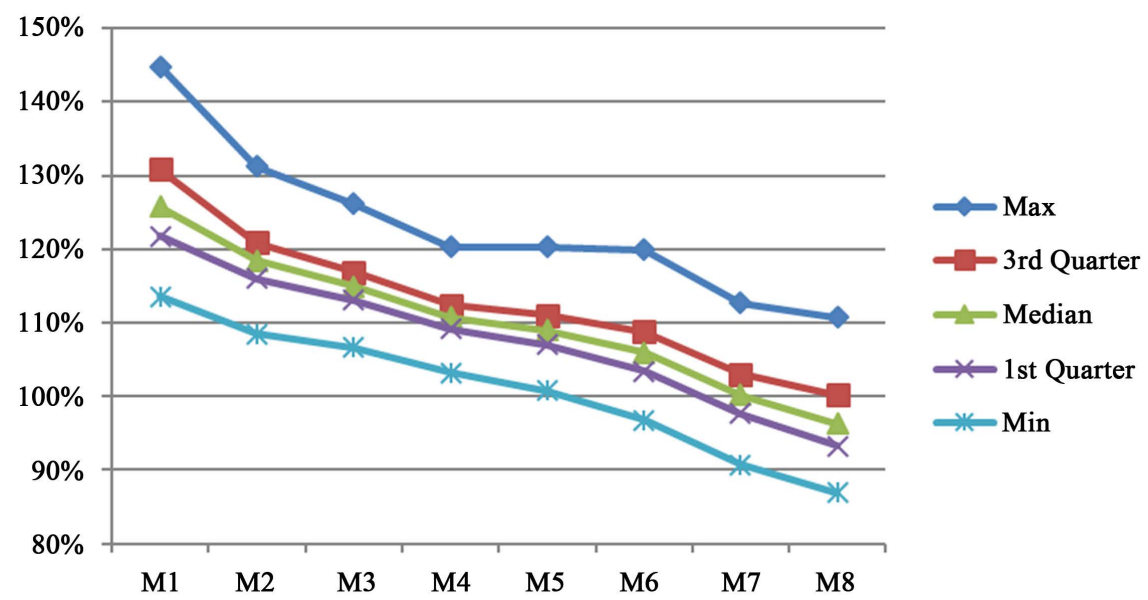

Figure 7. BMDI values variation with project time in a fron-end loaded bid.

\subsection{Back-End Loaded Bids}

In back-end loaded bids, late stage activities have bigger markups than early stage activities. Table 3 summarizes the computation of the BMDI values in a back-end loaded bid scenario Figure 8 shows an increasing pattern for the 5 BMDI trend lines. Moreover, the minimum maximum and middle trend lines follow the same direction.

\subsection{Quantity Error Exploitation Unbalanced Bids}

The bidder believes herein that the owner has underestimated the quantity amount of a bid item such as item E. To take advantage of this oversight, the bidder increased the unit price of item $\mathrm{E}$ and decreased the unit price of the other items expecting a bigger markup value for item $\mathrm{E}$ than for other items. Table 4 the computation of the BMDI values in the case of a back-end loaded bid. Figure 9 shows a spike in the 5 BMDI trend lines in the middle of the project when item $\mathrm{E}$ is active. This pattern is typical for Quantity Error Exploitation unbalanced bids.

\subsection{Risk Analysis}

There is always a risk that item unit costs vary in an uncontrolled manner. This affects not only the markup of that bid item but also the project markup. For example, let us consider that there is a risk that the expected cost of activity $\mathrm{G}$ increases from $\$ 7.13 / \mathrm{m}$ to $\$ 11.16 / \mathrm{m}$ (Table 5). This risk is reflected by a drop in minimum BMDI trend line as shown in Figure 10. This kind of pick/drop can be a sign of a risk in a BMDI graph.

\section{Conclusion}

One of the owners' main concerns during the bid evaluation process is to detect unbalanced bids. Any failure in this process not only increases the owner cost liability, but can also jeopardize the project success. This is due to the fact that 


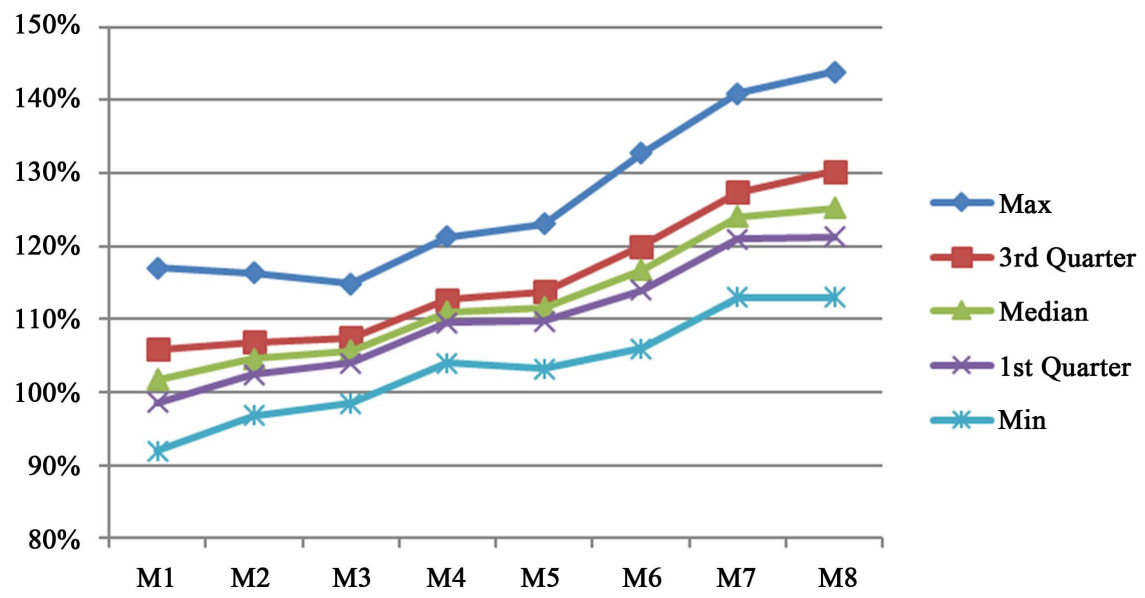

Figure 8. BMDI values variation with project time in a back-end loaded bid.

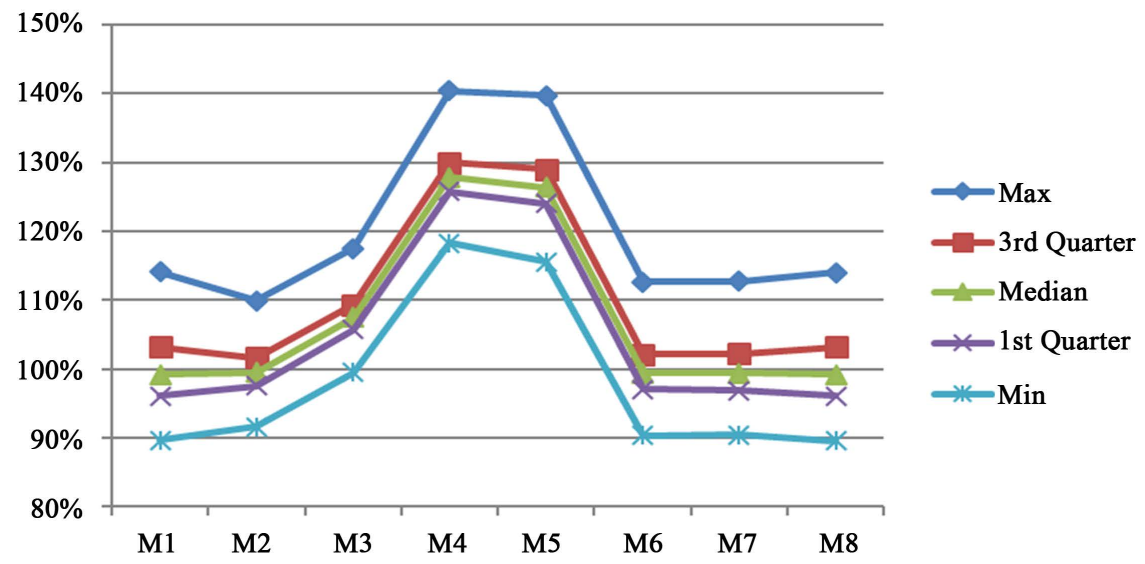

Figure 9. BMDI values variationwith project time for quantity error exploitation bids.

Table 3. Back-end loaded bid scenario.

\begin{tabular}{|c|c|c|c|c|c|c|c|c|c|}
\hline \multirow{2}{*}{ Bid items } & \multirow{2}{*}{ BIUP } & \multirow{2}{*}{ BIEUC } & \multirow{2}{*}{ Markup } & \multicolumn{3}{|c|}{ BIEQ } & \multicolumn{3}{|c|}{ BIEUC } \\
\hline & & & & Min & Most likely & Max & Min & Most likely & $\operatorname{Max}$ \\
\hline A & $4.22 \$ / \mathrm{m}$ & $4.00 \$ / \mathrm{m}$ & $106 \%$ & $65,835 \mathrm{~m}$ & $72,765 \mathrm{~m}$ & $83,160 \mathrm{~m}$ & $3.60 \$ / \mathrm{m}$ & $4.20 \$ / \mathrm{m}$ & $4.60 \$ / \mathrm{m}$ \\
\hline B & $12.02 \$ / \mathrm{m}$ & $11.20 \$ / \mathrm{m}$ & $107 \%$ & $27,930 \mathrm{~m}$ & $30,870 \mathrm{~m}$ & $35,280 \mathrm{~m}$ & $10.08 \$ / \mathrm{m}$ & $11.76 \$ / \mathrm{m}$ & $12.88 \$ / \mathrm{m}$ \\
\hline C & $5.41 \$ / \mathrm{m}$ & $5.00 \$ / \mathrm{m}$ & $108 \%$ & $33,250 \mathrm{~m}$ & $36,750 \mathrm{~m}$ & $42,000 \mathrm{~m}$ & $4.50 \$ / \mathrm{m}$ & $5.25 \$ / \mathrm{m}$ & $5.75 \$ / \mathrm{m}$ \\
\hline $\mathrm{D}$ & $4.97 \$ / \mathrm{m}$ & $4.55 \$ / \mathrm{m}$ & $109 \%$ & $27,930 \mathrm{~m}$ & $30,870 \mathrm{~m}$ & $35,280 \mathrm{~m}$ & $4.10 \$ / \mathrm{m}$ & $4.78 \$ / \mathrm{m}$ & $5.23 \$ / \mathrm{m}$ \\
\hline $\mathrm{E}$ & $11.53 \$ / \mathrm{m}$ & $10.00 \$ / \mathrm{m}$ & $115 \%$ & $25,935 \mathrm{~m}$ & $28,665 \mathrm{~m}$ & $32,760 \mathrm{~m}$ & $9.00 \$ / \mathrm{m}$ & $10.50 \$ / \mathrm{m}$ & $11.50 \$ / \mathrm{m}$ \\
\hline $\mathrm{F}$ & $5.32 \$ / \mathrm{m}$ & $4.80 \$ / \mathrm{m}$ & $111 \%$ & $53,200 \mathrm{~m}$ & $58,800 \mathrm{~m}$ & $67,200 \mathrm{~m}$ & $4.32 \$ / \mathrm{m}$ & $5.04 \$ / \mathrm{m}$ & $5.52 \$ / \mathrm{m}$ \\
\hline G & $6.77 \$ / \mathrm{m}$ & $6.20 \$ / \mathrm{m}$ & $109 \%$ & $53,865 \mathrm{~m}$ & $59,535 \mathrm{~m}$ & $68,040 \mathrm{~m}$ & $5.58 \$ / \mathrm{m}$ & $6.51 \$ / \mathrm{m}$ & $7.13 \$ / \mathrm{m}$ \\
\hline $\mathrm{H}$ & $5.86 \$ / \mathrm{m}$ & $5.30 \$ / \mathrm{m}$ & $111 \%$ & $33,250 \mathrm{~m}$ & $36,750 \mathrm{~m}$ & $42,000 \mathrm{~m}$ & $4.77 \$ / \mathrm{m}$ & $5.57 \$ / \mathrm{m}$ & $6.10 \$ / \mathrm{m}$ \\
\hline I & $12.24 \$ / \mathrm{m}$ & $10.50 \$ / \mathrm{m}$ & $117 \%$ & $21,280 \mathrm{~m}$ & $23,520 \mathrm{~m}$ & $26,880 \mathrm{~m}$ & $9.45 \$ / \mathrm{m}$ & $11.03 \$ / \mathrm{m}$ & $12.08 \$ / \mathrm{m}$ \\
\hline $\mathrm{J}$ & $10.11 \$ / \mathrm{m}$ & $8.50 \$ / \mathrm{m}$ & $119 \%$ & $29,260 \mathrm{~m}$ & $32,340 \mathrm{~m}$ & $36,960 \mathrm{~m}$ & $7.65 \$ / \mathrm{m}$ & $8.93 \$ / \mathrm{m}$ & $9.78 \$ / \mathrm{m}$ \\
\hline K & $4.21 \$ / \mathrm{m}$ & $3.50 \$ / \mathrm{m}$ & $120 \%$ & $51,870 \mathrm{~m}$ & $57,330 \mathrm{~m}$ & $65,520 \mathrm{~m}$ & $3.15 \$ / \mathrm{m}$ & $3.68 \$ / \mathrm{m}$ & $4.03 \$ / \mathrm{m}$ \\
\hline $\mathrm{L}$ & $8.03 \$ / \mathrm{m}$ & $6.30 \$ / \mathrm{m}$ & $128 \%$ & $53,200 \mathrm{~m}$ & $58,800 \mathrm{~m}$ & $67,200 \mathrm{~m}$ & $5.67 \$ / \mathrm{m}$ & $6.62 \$ / \mathrm{m}$ & $7.25 \$ / \mathrm{m}$ \\
\hline M & $65.18 \$ / \mathrm{m}$ & $50.20 \$ / \mathrm{m}$ & $130 \%$ & $5320 \mathrm{~m}$ & $5880 \mathrm{~m}$ & $6720 \mathrm{~m}$ & $45.18 \$ / \mathrm{m}$ & $52.71 \$ / \mathrm{m}$ & $57.73 \$ / \mathrm{m}$ \\
\hline \multicolumn{2}{|c|}{ Total Bid Value } & $3,813,699 \$$ & & & & & & & \\
\hline
\end{tabular}


B. Nikpour et al.

Table 4. Quantity error exploitation bid scenario.

\begin{tabular}{|c|c|c|c|c|c|c|c|c|c|}
\hline \multirow{2}{*}{ Bid items } & \multirow{2}{*}{ BIUP } & \multirow{2}{*}{ BIEUC } & \multirow{2}{*}{ Markup } & \multicolumn{3}{|c|}{ BIEQ } & \multicolumn{3}{|c|}{ BIEUC } \\
\hline & & & & Min & Most likely & Max & Min & Most likely & Max \\
\hline A & $4.12 \$ / \mathrm{m}$ & $4.00 \$ / \mathrm{m}$ & $103 \%$ & $65,835 \mathrm{~m}$ & $72,765 \mathrm{~m}$ & $83,160 \mathrm{~m}$ & $3.60 \$ / \mathrm{m}$ & $4.20 \$ / \mathrm{m}$ & $4.60 \$ / \mathrm{m}$ \\
\hline $\mathrm{B}$ & $11.52 \$ / \mathrm{m}$ & $11.20 \$ / \mathrm{m}$ & $103 \%$ & $27,930 \mathrm{~m}$ & $30,870 \mathrm{~m}$ & $35,280 \mathrm{~m}$ & $10.08 \$ / \mathrm{m}$ & $11.76 \$ / \mathrm{m}$ & $12.88 \$ / \mathrm{m}$ \\
\hline $\mathrm{D}$ & $4.68 \$ / \mathrm{m}$ & $4.55 \$ / \mathrm{m}$ & $103 \%$ & $27,930 \mathrm{~m}$ & $30,870 \mathrm{~m}$ & $35,280 \mathrm{~m}$ & $4.10 \$ / \mathrm{m}$ & $4.78 \$ / \mathrm{m}$ & $5.23 \$ / \mathrm{m}$ \\
\hline $\mathrm{E}$ & $25.00 \$ / \mathrm{m}$ & $10.00 \$ / \mathrm{m}$ & $250 \%$ & $25,935 \mathrm{~m}$ & $28,665 \mathrm{~m}$ & $32,760 \mathrm{~m}$ & $9.00 \$ / \mathrm{m}$ & $10.50 \$ / \mathrm{m}$ & $11.50 \$ / \mathrm{m}$ \\
\hline $\mathrm{F}$ & $4.94 \$ / \mathrm{m}$ & $4.80 \$ / \mathrm{m}$ & $103 \%$ & $53,200 \mathrm{~m}$ & $58,800 \mathrm{~m}$ & $67,200 \mathrm{~m}$ & $4.32 \$ / \mathrm{m}$ & $5.04 \$ / \mathrm{m}$ & $5.52 \$ / \mathrm{m}$ \\
\hline G & $6.38 \$ / \mathrm{m}$ & $6.20 \$ / \mathrm{m}$ & $103 \%$ & $53,865 \mathrm{~m}$ & $59,535 \mathrm{~m}$ & $68,040 \mathrm{~m}$ & $5.58 \$ / \mathrm{m}$ & $6.51 \$ / \mathrm{m}$ & $7.13 \$ / \mathrm{m}$ \\
\hline $\mathrm{H}$ & $5.45 \$ / \mathrm{m}$ & $5.30 \$ / \mathrm{m}$ & $103 \%$ & $33,250 \mathrm{~m}$ & $36,750 \mathrm{~m}$ & $42,000 \mathrm{~m}$ & $4.77 \$ / \mathrm{m}$ & $5.57 \$ / \mathrm{m}$ & $6.10 \$ / \mathrm{m}$ \\
\hline I & $10.80 \$ / \mathrm{m}$ & $10.50 \$ / \mathrm{m}$ & $103 \%$ & $21,280 \mathrm{~m}$ & $23,520 \mathrm{~m}$ & $26,880 \mathrm{~m}$ & $9.45 \$ / \mathrm{m}$ & $11.03 \$ / \mathrm{m}$ & $12.08 \$ / \mathrm{m}$ \\
\hline $\mathrm{J}$ & $8.75 \$ / \mathrm{m}$ & $8.50 \$ / \mathrm{m}$ & $103 \%$ & $29,260 \mathrm{~m}$ & $32,340 \mathrm{~m}$ & $36,960 \mathrm{~m}$ & $7.65 \$ / \mathrm{m}$ & $8.93 \$ / \mathrm{m}$ & $9.78 \$ / \mathrm{m}$ \\
\hline $\mathrm{K}$ & $3.60 \$ / \mathrm{m}$ & $3.50 \$ / \mathrm{m}$ & $103 \%$ & $51,870 \mathrm{~m}$ & $57,330 \mathrm{~m}$ & $65,520 \mathrm{~m}$ & $3.15 \$ / \mathrm{m}$ & $3.68 \$ / \mathrm{m}$ & $4.03 \$ / \mathrm{m}$ \\
\hline $\mathrm{L}$ & $6.48 \$ / \mathrm{m}$ & $6.30 \$ / \mathrm{m}$ & $103 \%$ & $53,200 \mathrm{~m}$ & $58,800 \mathrm{~m}$ & $67,200 \mathrm{~m}$ & $5.67 \$ / \mathrm{m}$ & $6.62 \$ / \mathrm{m}$ & $7.25 \$ / \mathrm{m}$ \\
\hline M & $51.66 \$ / \mathrm{m}$ & $50.20 \$ / \mathrm{m}$ & $103 \%$ & $5320 \mathrm{~m}$ & $5880 \mathrm{~m}$ & $6720 \mathrm{~m}$ & $45.18 \$ / \mathrm{m}$ & $52.71 \$ / \mathrm{m}$ & $57.73 \$ / \mathrm{m}$ \\
\hline \multicolumn{2}{|c|}{ Total Bid Value } & $3,813,697 \$$ & & & & & & & \\
\hline
\end{tabular}

Table 5. Risk analysis scenario.

\begin{tabular}{|c|c|c|c|c|c|c|c|c|c|}
\hline \multirow{2}{*}{ Bid items } & \multirow{2}{*}{ BIUP } & \multirow{2}{*}{ BIEUC } & \multirow{2}{*}{ Markup } & \multicolumn{3}{|c|}{ BIEQ } & \multicolumn{3}{|c|}{ BIEUC } \\
\hline & & & & Min & Most likely & $\operatorname{Max}$ & Min & Most likely & $\operatorname{Max}$ \\
\hline A & $4.57 \$ / \mathrm{m}$ & $4.00 \$ / \mathrm{m}$ & $114 \%$ & $65,835 \mathrm{~m}$ & $72,765 \mathrm{~m}$ & $83,160 \mathrm{~m}$ & $3.60 \$ / \mathrm{m}$ & $4.20 \$ / \mathrm{m}$ & $4.60 \$ / \mathrm{m}$ \\
\hline B & $12.78 \$ / \mathrm{m}$ & $11.20 \$ / \mathrm{m}$ & $114 \%$ & $27,930 \mathrm{~m}$ & $30,870 \mathrm{~m}$ & $35,280 \mathrm{~m}$ & $10.08 \$ / \mathrm{m}$ & $11.76 \$ / \mathrm{m}$ & $12.88 \$ / \mathrm{m}$ \\
\hline $\mathrm{D}$ & $5.20 \$ / \mathrm{m}$ & $4.55 \$ / \mathrm{m}$ & $114 \%$ & $27,930 \mathrm{~m}$ & $30,870 \mathrm{~m}$ & $35,280 \mathrm{~m}$ & $4.10 \$ / \mathrm{m}$ & $4.78 \$ / \mathrm{m}$ & $5.23 \$ / \mathrm{m}$ \\
\hline $\mathrm{E}$ & $11.53 \$ / \mathrm{m}$ & $10.00 \$ / \mathrm{m}$ & $115 \%$ & $25,935 \mathrm{~m}$ & $28,665 \mathrm{~m}$ & $32,760 \mathrm{~m}$ & $9.00 \$ / \mathrm{m}$ & $10.50 \$ / \mathrm{m}$ & $11.50 \$ / \mathrm{m}$ \\
\hline $\mathrm{F}$ & $5.48 \$ / \mathrm{m}$ & $4.80 \$ / \mathrm{m}$ & $114 \%$ & $53,200 \mathrm{~m}$ & $58,800 \mathrm{~m}$ & $67,200 \mathrm{~m}$ & $4.32 \$ / \mathrm{m}$ & $5.04 \$ / \mathrm{m}$ & $5.52 \$ / \mathrm{m}$ \\
\hline G & $7.40 \$ / \mathrm{m}$ & $6.20 \$ / \mathrm{m}$ & $119 \%$ & $53,865 \mathrm{~m}$ & $59,535 \mathrm{~m}$ & $68,040 \mathrm{~m}$ & $5.58 \$ / \mathrm{m}$ & $6.51 \$ / \mathrm{m}$ & $13.64 \$ / \mathrm{m}$ \\
\hline $\mathrm{H}$ & $6.03 \$ / \mathrm{m}$ & $5.30 \$ / \mathrm{m}$ & $114 \%$ & $33,250 \mathrm{~m}$ & $36,750 \mathrm{~m}$ & $42,000 \mathrm{~m}$ & $4.77 \$ / \mathrm{m}$ & $5.57 \$ / \mathrm{m}$ & $6.10 \$ / \mathrm{m}$ \\
\hline I & $11.90 \$ / \mathrm{m}$ & $10.50 \$ / \mathrm{m}$ & $113 \%$ & $21,280 \mathrm{~m}$ & $23,520 \mathrm{~m}$ & $26,880 \mathrm{~m}$ & $9.45 \$ / \mathrm{m}$ & $11.03 \$ / \mathrm{m}$ & $12.08 \$ / \mathrm{m}$ \\
\hline $\mathrm{J}$ & $9.72 \$ / \mathrm{m}$ & $8.50 \$ / \mathrm{m}$ & $114 \%$ & $29,260 \mathrm{~m}$ & $32,340 \mathrm{~m}$ & $36,960 \mathrm{~m}$ & $7.65 \$ / \mathrm{m}$ & $8.93 \$ / \mathrm{m}$ & $9.78 \$ / \mathrm{m}$ \\
\hline $\mathrm{K}$ & $4.04 \$ / \mathrm{m}$ & $3.50 \$ / \mathrm{m}$ & $115 \%$ & $51,870 \mathrm{~m}$ & $57,330 \mathrm{~m}$ & $65,520 \mathrm{~m}$ & $3.15 \$ / \mathrm{m}$ & $3.68 \$ / \mathrm{m}$ & $4.03 \$ / \mathrm{m}$ \\
\hline $\mathrm{L}$ & $7.21 \$ / \mathrm{m}$ & $6.30 \$ / \mathrm{m}$ & $114 \%$ & $53,200 \mathrm{~m}$ & $58,800 \mathrm{~m}$ & $67,200 \mathrm{~m}$ & $5.67 \$ / \mathrm{m}$ & $6.62 \$ / \mathrm{m}$ & $7.25 \$ / \mathrm{m}$ \\
\hline M & $57.40 \$ / \mathrm{m}$ & $50.20 \$ / \mathrm{m}$ & $114 \%$ & $5320 \mathrm{~m}$ & $5880 \mathrm{~m}$ & $6720 \mathrm{~m}$ & $45.18 \$ / \mathrm{m}$ & $52.71 \$ / \mathrm{m}$ & $57.73 \$ / \mathrm{m}$ \\
\hline \multicolumn{2}{|c|}{ Total Bid Value } & $3,813,698 \$$ & & & & & & & \\
\hline
\end{tabular}




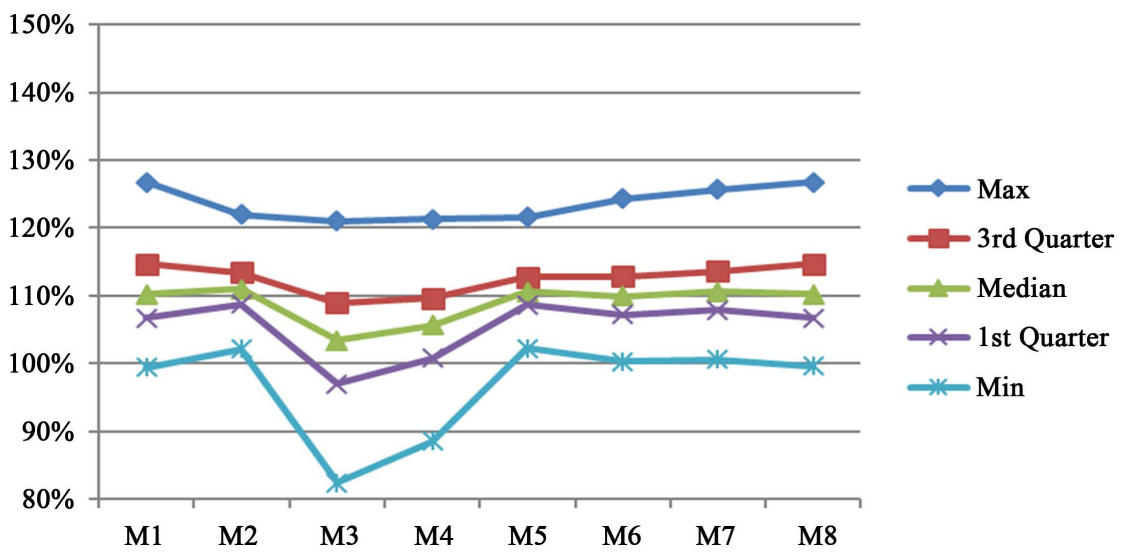

Figure 10. BMDI graph risk visualization.

most of unbalanced bidders lose their financial motivation during the project. Unfortunately, the bid evaluation process is usually conducted under time pressure. Moreover, the evaluators usually use unreliable and time consuming qualitative approaches to detect unbalanced bids. BMDI graphs are as an innovative visual detection tool that helps owners analyze and compare submitted bids and support their awarding process quickly and reliably. The tool visualizes project markup variation patterns during its lifetime to detect unbalanced bids. It also uses Monte Carlo simulation to take in consideration the impact of cost uncertainties and risks.

\section{References}

[1] Cui, Q.B., Hastak, M. and Halpin, D. (2010) Systems Analysis of Project Cash Flow Management Strategies. Construction Management and Economics, 28, 361-376. https://doi.org/10.1080/01446191003702484

[2] Cattell, D., Bowen, P. and Kaka, A. (2007) Review of Unbalanced Bidding Models in Construction. Journal of Construction Engineering \& Management, 133, 562-573. https://doi.org/10.1061/(ASCE)0733-9364(2007)133:8(562)

[3] McGreevy, S.L. (2002) Unbalanced Bids Are Risky Business. http://www.contractormag.com/articles/column.cfm?columnid=161

[4] Hyari, K., Tarawneh, Z. and Katkhuda, H. (2016) Detection Model for Unbalanced Pricing in Construction Projects: A Risk-Based Approach. Journal of Construction Engineering \& Management, 142, 1-10. https://doi.org/10.1061/(ASCE)CO.1943-7862.0001203

[5] Hoogenboom, J., Dale, W. and Martell, C. (2006) Risk Analysis and Optimization of the (Un)balanced Bid. AACE International transactions, 7, 1-6.

[6] Cattell, D., Bowen, P. and Kaka, A. (2008) A Simplified Unbalanced Bidding Model. Construction Management and Economics, 26, 1283-1290. https://doi.org/10.1080/01446190802570506

[7] Liu, X., Lin, L. and Zang, D. (2009) Stochastic Programming Models and Hybrid Intelligent Algorithm for Unbalanced Bidding Problem. Journal of Computing and Information Science in Engineering, 2, 188-194. https://doi.org/10.5539/cis.v2n1p188

[8] American Association of State Highway and Transportation Officials (2004) State 
DOT Procedures for the Evaluation of Materially Unbalanced Bids. American Association of State Highway and Transportation Officials, Washington DC.

[9] Wang, W. (2004) Electronic-Based Procedure for Managing Unbalanced Bids. Journal of Construction Engineering \& Management, 130, 455-460. https://doi.org/10.1061/(ASCE)0733-9364(2004)130:3(455)

[10] Arditi, D. and Chotibhongs, R. (2009) Detection and Prevention of Unbalanced Bids. Construction Management and Economics, 27, 721-732. https://doi.org/10.1080/01446190903117785

[11] Shrestha, P.P., Shrestha, K. and Joshi, V. (2012) Investigation of Unbalanced Bidding for Economic Sustainability. Proceedings of International Conference on Sustainable Design, Engineering, and Construction, Fort Worth, 7-9 November 2012, 609-615.

[12] Skitmore, M. and Cattell, D. (2013) On Being Balanced in an Unbalanced World. Journal of the Operational Research Society, 64, 138. https://doi.org/10.1057/jors.2012.29

[13] Hyari, K.H. (2015) Handling Unbalanced Bidding in Construction Projects: Prevention Rather than Detection. Journal of Construction Engineering \& Management, 142, 1-10. https://doi.org/10.1061/(ASCE)CO.1943-7862.0001045

[14] Afshar, A. and Amiri, H. (2010a) A Min-Max Regret Approach to Unbalanced Bidding in Construction. KSCE Journal of Civil Engineering, 14, 653-661. https://doi.org/10.1007/s12205-010-0972-0

[15] Afshar, A. and Amiri, H. (2010b) Risk-Based Approach to Unbalanced Bidding in Construction Projects. Optim Engineering, 42, 369-385. https://doi.org/10.1080/03052150903220964

[16] Peterson, S.J. (2009) Construction Accounting and Financial Management. Pearson Education, Inc., Upper Saddle River.

[17] Mincks, W.R. and Johnston, H. (2011) Construction Jobsite Management. 3rd Edition, Delmar Cengage Learning, Clifton Park.

[18] Shim, E. and Kim, S.J. (2016) Cost Item-Based Markup Distribution in Construction Projects. The Journal of Technology, Management, and Applied Engineering, 32, 1-26.

\section{Scientific Research Publishing}

Submit or recommend next manuscript to SCIRP and we will provide best service for you:

Accepting pre-submission inquiries through Email, Facebook, LinkedIn, Twitter, etc. A wide selection of journals (inclusive of 9 subjects, more than 200 journals)

Providing 24-hour high-quality service

User-friendly online submission system

Fair and swift peer-review system

Efficient typesetting and proofreading procedure

Display of the result of downloads and visits, as well as the number of cited articles

Maximum dissemination of your research work

Submit your manuscript at: http://papersubmission.scirp.org/

Or contact ojce@scirp.org 